\title{
Hyperglycemia, Lumbar Plexopathy and Hypokalemic Rhabdomyolysis Complicating Conn's Syndrome
}

\author{
Chi-Ping Chow, Christopher J. Symonds and Douglas W. Zochodne
}

\begin{abstract}
Background: Lumbosacral plexopathy is a complication of diabetes mellitus. Conn's syndrome from an aldosterone secreting adenoma may be associated with hypokalemia and rhabdomyolysis but mild hyperglycemia also usually occurs. Methods: Case description. Results: A 70-year-old male diagnosed as having Conn's syndrome, hypokalemia and mild hyperglycemia developed rhabdomyolysis and lumbar plexopathy as a presenting feature of his hyperaldosteronism. His rhadbdomyolysis rapidly cleared following correction of hypokalemia but recovery from the plexopathy occurred slowly over several months. Definite resection of the aldosterone secreting adenomas reversed the hyperglycemia. Conclusions: Our patient developed lumbar plexopathy resembling that associated with diabetes mellitus despite the presence of only mild and transient hyperglycemia.
\end{abstract}

RÉSUMÉ: Hyperglycémie, plexopathie lombaire et rhabdomyolyse hypokaliémique compliquant le syndrome de Conn. Introduction: La plexopathie lombosacrée est une complication du diabète. Le syndrome de Conn dû à un adénome sécrétant de l'aldostérone peut être associé à une hypokaliémie et à un rhabdomyolyse, mais une légère hyperglycémie peut aussi être présente. Méthode: Description d'un cas. Résultats: Un patient âgé de 70 ans porteur d'un syndrome de Conn, d'une hypokaliémie et d'une légère hyperglycémie a développé une rhabdomyolyse et une plexopathie lombaire comme manifestation initiale de son hyperaldostéronisme. La rhabdomyolyse s'est résolue rapidement suite à la correction de l'hypokaliémie, mais la guérison de sa plexopathie a pris plusieurs mois. La résection définitive de l'adénome sécrétant de l'aldostérone a fait disparaître l'hyperglycémie. Conclusions: Notre patient a développé une plexopathie lombosacrée ressemblant à une plexopathie diabétique bien que son hyperglycémie n'ait été que légère et transitoire.

Can. J. Neurol. Sci. 1997; 24: 67-69

The combination of pain, weakness, wasting and diminished reflexes in the thigh without major objective signs of sensory impairment was described by Garland in $1955 .^{1}$ The same disorder has subsequently been termed as diabetic amyotrophy, diabetic polyradiculopathy, diabetic femoral neuropathy, proximal diabetic neuropathy or diabetic lumbosacral plexopathy. We will report a case of lumbar plexopathy associated with transient hyperglycemia, hypokalemic rhabdomyolysis and aldosterone secreting adrenal adenomas.

\section{Case Report}

A 70-year-old retired carpenter was admitted to hospital with a history of retrosternal chest pain for one day and progressive leg weakness for one week. Weakness was first noticed on the left leg and it later involved the right. On admission, he was not able to walk without assistance. He had a ten year history of hypertension treated with nifedipine, diltiazem and acebutolol, and a two year history of prostatic enlargement. Four months prior to admission he was found to have elevated random glucose of $10.3 \mathrm{mmol} / \mathrm{L}$, a hemoglobin $\mathrm{A}_{1} \mathrm{C}$ level of $6.1 \%$ (normal range: $4.3-6.1 \%$ ) and a low potassium level of $2.9 \mathrm{mmol} / \mathrm{L}$. He was given spironolactone and potassium supplement but he stopped taking these a few weeks prior to admission.

Physical examination showed a blood pressure of $155 / 85 \mathrm{~mm} \mathrm{Hg}$ without postural change. He had mild ankle edema without jugular venous distention. The apical pulse was irregular at 160 per minute. There was no clinical evidence of Cushing's syndrome. He had normal higher mental function and cranial nerves. Muscle bulk and tone were normal. Power (MRC scale) of various muscle groups were as follows: shoulder abductors right $5 / 5$ left $5 / 5$, elbow flexors right $4 / 5$ left $4+15$, elbow extensors right $4+/ 5$ left $5 / 5$, wrist flexors right $4 / 5$ left $5 / 5$, wrist extensors right $4 / 5$ left $5 / 5$, finger flexors and extensors right $5 / 5$ left $5 / 5$, hip flexors right $4 / 5$ left $2 / 5$, knee extensors right $4+/ 5$ left $3+15$, knee flexors right $5 / 5$ left $4+/ 5$, both ankle dorsiflexors and plantar flexors $5 / 5$. The left quadriceps reflex was absent and all other tendon reflexes were normal. Sensory testing was normal.

The following studies were normal: complete blood count, ESR, calcium, albumin, magnesium, alkaline phosphatase, alanine aminotransferase and bilirubin. Abnormal findings were: potassium $1.8 \mathrm{mmol} / \mathrm{L}$ $(\mathrm{N}>3.5)$, creatinine $188 \mathrm{mmol} / \mathrm{L}(\mathrm{N}<120)$, random glucose $16.4 \mathrm{mmol} / \mathrm{L}$ $(\mathrm{N}<8.0)$, creatine kinase $1017 \mathrm{U} / \mathrm{L}(\mathrm{N}<180)$, urine dip test $1+$ glucose, $2+$ protein and large for blood. Microscopy of the urine showed only 3$5 \mathrm{RBC} / \mathrm{HPF}$ suggesting myoglobinuria but the serum myoglobin was negative. Urine biochemistry showed inappropriately high potassium

From the Department of Clinical Neurosciences and The Neuroscience Research Group, The University of Calgary, Calgary.

RECEIVED JUNE 3, 1996. ACCEPTED IN FINAL. FORM SEPTEMBER 5, 1996.

Reprint requests to: Dr. D.W. Zochodne. The University of Calgary, Department of Clinical Neurosciences, Room 182A, 3330 Hospital Drive N.E., Calgary, Alberta, Canada $\mathrm{T} 2 \mathrm{~N} 4 \mathrm{~N} \mathrm{I}$ 
level of $36 \mathrm{mmol} / \mathrm{L}$ despite the low serum potassium. Electrocardiogram on admission showed presence of atrial fibrillation with rapid ventricular rate of 150 .

The patient was admitted to the coronary care unit and rapid atrial fibrillation was controlled with intravenous diltiazem and sotalol. Intravenous potassium replacement was given and cardiac rhythm reverted to sinus spontaneously. His creatine kinase level peaked at $2799 \mathrm{U} / \mathrm{L}$ one day after admission (normal MB fraction). His serum potassium level normalized and his muscle power gradually improved. His blood glucose remain elevated and a fasting level five days later was $10.3 \mathrm{mmol} / \mathrm{L}$. $\mathrm{HbA} \mathrm{C}$ was borderline elevated to $6.2 \%$ (normal range $4.3-6.1 \%$ ). Pelvic and abdominal ultrasound was normal. MRI of the lumbar intraspinal space and lumbosacral plexus was normal. Renal imaging the $\mathrm{Tc} 99 \mathrm{~m} \mathrm{Mag}^{3}$ ( $350 \mathrm{MBQ}$ ) with captopril showed moderate bilateral renal impairment without renal artery stenosis.

Nerve conduction studies and electromyography were performed five days after admission. Motor and sensory conduction studies of the right median, ulnar and radial nerves were normal. Bilateral femoral nerve stimulation at the inguinal area showed identical distal motor latencies but the amplitude of the motor response over vastus medialis was $50 \%$ smaller on the left. Motor studies of the left tibial, and both peroneal nerves and sensory study of the left sural nerve identified reduced amplitudes of the respective potentials (Table). Needle electromyography of the left iliopsoas and rectus femoris both showed increased insertional activity, positive sharp waves and fibrillation potentials. The number of motor units was decreased and the firing rate increased. Studies on the left tibialis anterior and medial gastrocnemius were normal. The findings suggested denervation of the left lumbar plexus. The patient was judged to have a left lumbar plexopathy, with superimposed rhabdomyolysis. With correction of his potassium, his upper limbs and right lower limb strength rapidly recovered but he retained significant weakness of the left lower limb. Mild hyperglycemia and borderline hypokalemia persisted.

Table: Nerve Conduction Studies.

\begin{tabular}{|c|c|c|c|c|}
\hline $\begin{array}{l}\text { Days after } \\
\text { Admission }\end{array}$ & Nerve and Site & $\begin{array}{l}\text { Latency } \\
\text { ms }\end{array}$ & $\begin{array}{l}\text { Amplitude } \\
\mathrm{mV} / \mathrm{uV}\end{array}$ & $\begin{array}{l}\mathrm{CV} \\
\mathrm{m} / \mathrm{s}\end{array}$ \\
\hline 5 days & $\begin{array}{l}\text { Peroneal L (motor) } \\
\text { ankle } \\
\text { knee } \\
\text { Tibial L (motor) } \\
\text { ankle } \\
\text { knee } \\
\text { Sural L (sensory) } \\
\text { ankle } \\
\text { Femoral R (motor) } \\
\text { groin } \\
\text { Femoral L (motor) } \\
\text { groin }\end{array}$ & $\begin{array}{l}4.6 \\
13.7 \\
4.0 \\
13.3 \\
3.0 \\
6.1 \\
6.1\end{array}$ & $\begin{array}{l}2.2 \\
2.1 \\
0.5 \\
0.7 \\
3 \\
6.2 \\
3.2\end{array}$ & 42.5 \\
\hline 3 months & $\begin{array}{l}\text { Peroneal L (motor) } \\
\text { ankle } \\
\text { fibular head } \\
\text { knee } \\
\text { Femoral L (motor) }\end{array}$ & $\begin{array}{l}4.5 \\
12.1 \\
14.3 \\
\mathrm{NR}\end{array}$ & $\begin{array}{l}3.4 \\
3.0 \\
2.9\end{array}$ & $\begin{array}{l}41 \\
48\end{array}$ \\
\hline 8 months & $\begin{array}{l}\text { Femoral R (motor) } \\
\text { groin } \\
\text { Femoral L (motor) } \\
\text { groin }\end{array}$ & $\begin{array}{l}5.5 \\
6.5 \\
\end{array}$ & $\begin{array}{l}6.1 \\
1.1 \\
\end{array}$ & \\
\hline 18 months & $\begin{array}{l}\text { Peroneal L (motor) } \\
\text { ankle } \\
\text { fibular head } \\
\text { knee } \\
\text { Femoral R (motor) } \\
\text { groin } \\
\text { Femoral L (motor) } \\
\text { groin }\end{array}$ & $\begin{array}{l}5.8 \\
13.6 \\
16.0 \\
6.0 \\
6.6\end{array}$ & $\begin{array}{l}4.4 \\
4.0 \\
3.8 \\
\\
8.6 \\
\\
2.5\end{array}$ & $\begin{array}{l}38 \\
46\end{array}$ \\
\hline
\end{tabular}

In view of his rapid improvement, muscle biopsy was not requested. Cutaneous nerve biopsy from the plexus was also not requested. At 3 months he had weakness confined to the left quadriceps $(3+/ 5 \mathrm{MRC})$, wasting of the left quadriceps, an absent quadriceps reflex and mild sensory loss at the left knee. Repeat electrophysiological studies identified dense runs of fibrillation potentials and positive sharp waves in left ileopsoas, left gracilis and rectus femoris. Motor unit potentials were reduced in number, but enlarged in amplitude and duration indicating previous denervation with reinnervation.

Endocrinologic investigation demonstrated a profoundly suppressed plasma renin activity and elevated serum aldosterone concentration (serum aldosterone [pmol/L]: 3251 at 0800 and 4673 at 1200 ; reference values in patients with benign hypertension $132 \pm 95$ [SD] and $415 \pm 456$ respectively; renin $0.02 \mathrm{ng} / \mathrm{L} / \mathrm{S}$; reference recumbent value $>0.08$; see reference 2). Computed tomographic scan of the abdomen showed a 2.0 $\mathrm{cm}$ mass of the right adrenal gland. Subsequent bilateral adrenal vein sampling studies revealed localization of aldosterone secretion to the right adrenal gland (right adrenal aldosterone/cortisol ratio 23.58; left adrenal/cortisol ratio 2.80; see reference 2) and confirmed the diagnosis of Conn's syndrome. ${ }^{2,3}$ A laparoscopic right adrenalectomy was performed. Pathological examination of the right adrenal showed two nodules identified as aldosterone secreting ademomas. Histologic study identified nests and cords of clear and oxyphilic cells without necrosis, mitoses or nuclear pleomorphism. Postoperatively hyperglycemia and hypokalemia resolved, the hypertension improved and there was further improvement of his left lumbar plexopathy. Two months postoperatively the hemoglobin $\mathrm{A}_{1} \mathrm{C}$ level was $5.4 \%$ (normal range: $4.3 \%-6.1 \%$ ).

\section{Discussion}

Our patient presents with two interesting neuromuscular complications of Conn's syndrome: (i) lumbar plexopathy resembling that of diabetes and (ii) hypokalemic rhabdomyolysis. Although a muscle biopsy was not requested, we suggest that the patient had comparatively mild rhabdomyolysis because of the elevated CK, patchy weakness that rapidly recovered, and abnormal urine dipstick.

Conn in $1965^{4}$ reported a series of 27 patients with primary hyperaldosteronism due to adrenal adenoma. Fourteen (52\%) of these patients were found to have impaired glucose tolerance and such impairment was reversible after the removal of the adenoma. ${ }^{4}$ Studies by Podolsky and Melby in 1976 demonstrated impairment of both insulin and growth hormone responses to stimulation in primary hyperaldosteronism with potassium depletion. ${ }^{5}$ These abnormalities were reversed with potassium repletion. An abnormal glucose tolerance test in patients with hypokalemia can be corrected with normalization of the serum potassium level. ${ }^{4,6}$

There are several reported studies of myopathy associated with hyperaldosteronism..$^{7-10}$ Histological examination of muscle, not obtained in our case has shown: (i) vacuolated muscle fibers; (ii) tubular aggregates within the muscle fibers; (iii) fiber atrophy (Type 2A); (iv) muscle fiber necrosis; (v) central nuclei; (vi) dilation of the sarcoplasmic reticulum; (vii) regenerating fibers in the acute stage.

Diabetic lumbar plexopathy occurs in the sixth or seventh decade. It is most common in mild diabetes mellitus controlled by diet or oral hypoglycemic drugs but it can occur at any stage of diabetes. It may be a presenting symptom of diabetes. The onset of this focal neuropathy has no constant relationship with glycemic control at the time and in some cases develops within weeks of starting insulin therapy.

To our knowledge there is no previous report of hyperglycemia and plexopathy associated with Conn's syndrome or hypokalemia. Our patient was found to have elevated blood 
glucose on at least three occasions (before, during and after the admission) presumably secondary to the suppression of insulin secretion by the profound hypokalemia of hyperaldosteronism. Hemoglobin $A_{1} C$ levels were only mildly elevated, arguing against persistent, severe or chronic hyperglycemia. A level of $6.2 \%$ suggests an average blood glucose of 6.4 over the preceding three weeks. His lumbar plexopathy resembled that of diabetes yet his hypergylcemia was mild and transient. No other structural cause, however, of plexopathy was identified despite careful imaging of the plexus. In addition, the plexopathy improved spontaneously, as occurs in diabetes, even before definitive resection of the adenomas. Diabetic lumbosacral plexopathy is thought to be ischemic in origin. ${ }^{11}$

Unprovoked, severe hypokalemia in a hypertensive patient is a strong clue to the presence of Conn's syndrome. ${ }^{12}$ Conn's syndrome has been reported to be associated with proximal muscle weakness, muscle tenderness and rhabdomyolysis. ${ }^{13}$ Frank rhabdomyolysis with marked elevation of serum muscle enzymes and myoglobinuria has been observed when serum potassium is below $2.0 \mathrm{mmol} / \mathrm{L} .{ }^{14}$ Potassium released from normal contracting muscle cells into interstitial fluid of the muscle directly probably dilates neighbouring arterioles. ${ }^{15}$ Rhabdomyolysis, in turn, may occur in hypokalemia because of ischemia due to subnormal potassium mediated arteriolar dilation. It is uncertain whether a similar mechanism might involve the vasa nervorum of the lumbar plexus.

\section{ACKNOWLEDGEMENTS}

Brenda Boake provided expert secretarial assistance. DWZ is a medical scholar of the Alberta Heritage Foundation for Medical Research.

\section{REFERENCES}

1. Garland H. Diabetic amyotrophy. Br Med J 1955; 26: 1287-1290.

2. Vaughan NJA, Jowett TP, Slater JDH, et al. The diagnosis of primary hyperaldosteronism. Lancet 1981: 120-125.

3. Melby JC, Spark RF, Dale S, et al. Diagnosis and localization of aldosterone-producing adenomas by adrenal vein catheterization. N Engl J Med 1967; 277: 1050-1056.

4. Conn JW. Hypertension, the potassium ion and impaired carbohydrate tolerance. N Engl J Med 1965; 273: 1135-1143.

5. Podolsky S, Melby JC. Improvement of growth hormone response to stimulation in primary aldosteronism with correction of potassium deficiency. Metabolism 1976; 25: 1027-1032.

6. Gorden P. Glucose intolerance and hypokalemia: failure of short term potassium depletion in normal subjects to reproduce the glucose and insulin abnormalities of clinical hypokalemia. Diabetes 1973; 22: 544-551.

7. Gallai, M. Myopathy with hyperaldosteronism. J Neurol Sci 1977; 32: 337-345.

8. Bautista J, Gil-Neciga E, Gil-Peralta A. Hypokalemic periodic paralysis in primary hyperaldosteronism. Eur Neurol 1979; 18: 415-420.

9. Sambrook MA, Heron JR, Aber GM. Myopathy in association with primary hyperaldosteronism. J Neuro Neursurg Psychiatry 1972; 35: 202-207.

10. Atsumi T, Ishikawa S, Miyatake T, Yoshida M. Myopathy and primary aldosteronism: electronmicroscopic study. Neurology 1979; 29: 1348-1353.

11. Raff MC, Sangalang V, Asbury AK. Ischemic mononeuropathy multiplex associated with diabetes mellitus. Arch Neurol 1968; 18: 487-499.

12. Weinberger $\mathrm{MH}$, Grim $\mathrm{CE}$, Hollifield $\mathrm{W}$, et al. Primary aldosteronism: diagnosis, localization, and treatment. Ann Intern Med 1979; 90: 386-395.

13. Dominic JA, Koch M, Guthrie GP, et al. Primary aldosteronism presenting as myoglobinuric acute renal failure. Arch Intern Med 1978; 138: 1433-1434.

14. Mijares RP. Hypokalemic rhabdomyolysis secondary to pseudohyperaldosteronism due to the use of a lotion containing 9-alphafluoroprednisolone. Nephron 1986; 43: 232-233.

15. Knochel PL, Schlein EM. On the mechanism of rhabdomyolysis in potassium depletion. J Clin Invest 1972; 51: 1750-1758. 